\title{
Metal forms in bottom sediments as a bioavailability indicator
}

\author{
Malgorzata Wojtkowska ${ }^{1}$ \\ 1. Faculty of Building Services, Hydro and Environmental Engineering, Warsaw University of Technology, \\ POLAND, 00-653 Warsaw, ul. Nowowiejska 20, E-mail: malgorzata.wojtkowska@ pw.edu.pl
}

Abstract. This study assessed the risk of water biocenosis caused by the potentially bioavailable metal forms. In a simple extraction process, the efficiency of metals eluting from the sediments was highest for EDTA solution. Sequential extraction has confirmed the diverse bioavailability of metals in the aquatic environment.

Keywords: metals, sediments, single and sequential speciation, bioavailability

\section{Introduction}

Upon reaching water, metals react with substances contained in it, then settle on the bottom and react with the sediment components. The most important processes of metal immobilization in sediments are: chemisorption, precipitation, co-precipitation and complexation [1, 2]. In mineral structures, ion of $\mathrm{K}^{+}$or $\mathrm{Ca}^{2+}$ can be exchanged for other ion metals $\left(\mathrm{Me}^{2+}\right)$, e.g in clay or shells. Carbonates and phosphates are other important components in these processes. Chemisorption and co-precipitation of metals heavily depends on the presence of hydrated $\mathrm{Fe} / \mathrm{Mn}$ oxides. These metals are chemically reactive in their reduced form of $\mathrm{Fe}(\mathrm{II})$ and $\mathrm{Mn}$ (II), and insoluble forms are present in the oxidized compounds Mn(III, IV), Fe(III). On the surface of these compounds sorption of hydrogen ions or of metal cations occurs as following [3]:

$$
\mathrm{FeO}(\mathrm{OH})+\mathrm{Me}^{2+} \leftrightarrow \mathrm{FeO}(\mathrm{OH})-\mathrm{M} \leftrightarrow(\mathrm{FeO}(\mathrm{O})-\mathrm{Me})^{+}+\mathrm{H}^{+}
$$

Karczewska [4] showed, that manganese oxides bind 1-30\% of total $\mathrm{Cu}$ content, 1-26\% of $\mathrm{Pb}, 4-27 \%$ of $\mathrm{Zn}$ and $<1 \%$ of $\mathrm{As}$, amorphous iron oxides bind $3-24 \% \mathrm{Cu}, 1-54 \% \mathrm{~Pb}, 3-25 \% \mathrm{Zn}$ and $42-90 \% \mathrm{As}$, and crystalline oxides: $3-29 \% \mathrm{Cu}, 1-53 \% \mathrm{~Pb}, 9-34 \% \mathrm{Zn}$ and 5-46\% As.

An equally important solid phase of metal binding in sediments are sulfides (eg. FeS), in which iron can be replaced with another metal, according to the equation:

$$
\mathrm{Me}^{2+}+\mathrm{FeS}_{(\mathrm{s})}===\mathrm{MeS}_{(\mathrm{s})}+\mathrm{Fe}^{2+}
$$

Metals bound in sulfides can be released under appropriate conditions into an aqueous solution.

The high contribution of $\mathrm{Cd}$ in mobile sediment forms may be due to the process in which cadmium sulfide is partially or completely oxidized to a soluble form of $\mathrm{CdSO}_{4}$ under aerobic conditions:

$$
\mathrm{CdS}(\mathrm{s})+2 \mathrm{O}_{2}==\mathrm{Cd}^{2+}+\mathrm{SO}_{4}{ }^{2-}
$$

This reaction is very likely to happen in the shallow river sediments, where near-bottom layers of the river are well oxygenated and where variable hydrological conditions along with redox potential changes at the water- sediment boundary can be observed.

The chemical composition of bottom sediments is in many cases a better environmental pollution indicator than the water composition. The content of chemical elements changes between the sediment layers, showing the historical contamination changes of the reservoir [5].

In environmental studies of bottom sediment samples, the total metal content is the most popular indicator, because it shows the extent of sediment contamination. Bioavailability and mobility may be assessed by using a single (simple) extraction, where the natural conditions of components passing from the testing sample directly to the solution are simulated [6]. The single extraction method consists of applying the extrahent to the sediment sample to determine the metal forms, which then pass to the extraction solution. It reflects the biological metal 
bioavailability by plants or organisms and the susceptibility of the metal leaching [7]. In a single extraction, the following solutions are used: neutral solutions $\left(\mathrm{H}_{2} \mathrm{O}, \mathrm{CH}_{3} \mathrm{COONH}_{4}\right)$, complex metal solutions (EDTA, NTA. DTPA) or high ionic strength solutions $\left(\mathrm{CaCl}_{2}, \mathrm{MgCl}_{2}\right)$ which cause the release of adsorbed ingredients $[8,9]$. Extraction with $\mathrm{MgCl}_{2}$ solution can be a measure of the metals availability, which are deposited in sediments in natural environmental conditions [7]. Forms of metals released during the EDTA extraction are forms that are potentially available during the variable environmental conditions $(\mathrm{pH}$, redox potential) [8]. In addition to the single extraction, a sequential extraction is used. This method is applied to separate forms of heavy metals, which can be released into the solution under various environmental conditions.

The first examples of sequential extraction of bottom sediments and soil are from the 1970s. Sequential extraction methods are based on the gradual release of metals in various forms. These methods involve a use of series of solutions with increasing leaching power. The most widespread and commonly used procedure for sequential extraction of five fractional metal fractions from bottom sediments is the Tessier procedure, currently used with minor modifications [10]. In order to obtain comparable results, which would allow for precise interpretation and application in environmental monitoring, it was essential to standardize the procedure for testing metal forms in bottom sediments. Recent years have brought attempts to standardize the research methods, eg. by the Community Bureau of Reference (BRC) [9]. In order to compare results, the European Commission, under the Standard Measurement and Testing Program (SM\&T), has adopted common procedures for the heavy metals extraction, both for single and sequential methods. For the heavy metals single extraction it is recommended to use EDT A $/ \mathrm{CH}_{3} \mathrm{COONH}_{4}$ solutions. This method allows to determine the metals bioavailability in sediments. Ure et al. [9] have developed a triple-step sequential extraction procedure called $\mathrm{BRC}$ in order to standardize the sequential speciation conditions. In the procedure approved by SM\&T, Tessier's two fractions were considered to be mobile equivalent. The proposed BRC method is expanded by introducing a fourth extraction step, that allows to determine the residual fraction.

Detailed environmental studies allow to control the natural processes that govern the heavy metals recycling cycle in surface water, including toxicity reduction and tracking the dynamics in the changes of the heavy metals forms in the water- sediment system. Forms of heavy metals $(\mathrm{Zn}, \mathrm{Cu}, \mathrm{Pb}$ and $\mathrm{Cd}$ ) were investigated in bottom sediments, by using speciation analysis (single and sequential). This allowed us to assess the risk of bioavailable metals in surface water. In order to achieve the goal of the research, the sediments contaminated with metals were obtained from Utrata river (Poland) [11]. The obtained results allowed us to characterize the relationship between heavy metal forms present in bottom sediments and their environmental bioavailability.

\section{Materials and methods. Bottom sediments}

The samples of bottom sediments obtained from the Utrata river (Poland) were highly contaminated with metals. $\mathrm{Zn}, \mathrm{Cu}, \mathrm{Pb}$ and $\mathrm{Cd}$ contents were analysed in the surface layer of bottom sediments of $5 \mathrm{~cm}$ thickness. Metal content was defined for dry sediments fractions with the particle diameter $<0.090 \mathrm{~mm}$. $1 \mathrm{~g}$ of sediment sample was taken from the separated fraction.

\section{Determination of the heavy metals content in sediments}

The content of the selected heavy metals $(\mathrm{Zn}, \mathrm{Cd}, \mathrm{Pb}$ and $\mathrm{Cu})$ in the sediment samples was measured by flame atomic absorption spectroscopy (FAAS) based on the standard curves determined for a series of pre-prepared standard solutions by MERC company. Prior to the 
measurement, the dry mineralization and extraction of the sediment sample was performed. The detection limits for individual metals were calculated for the double standard deviation of five replicates in sediments (expressed as $\mathrm{mg} / \mathrm{kg}$ dry matter): $\mathrm{Cd}(0,005), \mathrm{Cu}(0,03), \mathrm{Pb}(0,05), \mathrm{Zn}$ $(0,01)$. In order to verify the correctness of the analysis and the measurement accuracy, a certified reference material Till-3 CRM with a known metal content was mineralized (Tab. 1). Metals recovery percentage from reference sediments varied between 93-110\%. The error resulting from the comparison of the analysis results, did not exceed $10 \%$.

Table. 1 .

Content of metals in the certified material Till-3

\begin{tabular}{|c|c|c|c|}
\hline Metal & $\begin{array}{c}\text { Mineralization in HNO3 } \\
\mathrm{HClO} 4(\mathrm{mg} / \mathrm{kg})\end{array}$ & $\begin{array}{c}\text { Content in CRM } \\
(\mathrm{mg} / \mathrm{kg})\end{array}$ & Recovery \% \\
\hline $\mathrm{Cu}$ & 21,5 & 23,0 & 93,5 \\
$\mathrm{Zn}$ & 45,5 & 43 & 105,6 \\
$\mathrm{~Pb}$ & 21,8 & 20,3 & 107,4 \\
$\mathrm{Cd}$ & 5,9 & 5,3 & 111,3 \\
\hline
\end{tabular}

\section{Total metal content}

The total metal content was determined in solutions obtained after mineralization of $1 \mathrm{~g}$ of air dried sediment with a mixture of acids $\left(9 \mathrm{ml} \mathrm{HNO}_{3}, 3 \mathrm{ml} \mathrm{HClO} 4\right)$. The process of mineralization was carried out in a mineralization block, where the sample of bottom sediment and acids mixture were placed in a teflon pot. The solution obtained after mineralization was filtrated into a flask with volume of $100 \mathrm{ml}$.

\section{Simple extraction}

The effects of metal extraction from air dried bottom sediments using distilled water and solutions of: $1 \mathrm{M} \mathrm{MgCl} 2$ and $0.05 \mathrm{M}$ EDTA were determined in laboratory conditions. The extraction solution was obtained after mixing the sediment with an extractant in a weight ratio of $10 \mathrm{~g}$ sediment $/ 100 \mathrm{ml}$. The extraction was carried out for 1 hour. All metal assays were performed three times, giving as a result the average value.

\section{Sequential extraction}

Tessier sequence was used to determine the metal forms in the air dried bottom sediments [10]. In the extraction five fractions of metal bonds were isolated. Exchangeable fraction (F1) $1 \mathrm{~g}$ of a material was supplied with $8 \mathrm{ml}$ of $1 \mathrm{~mol} / 1 \mathrm{MgCl}_{2}(\mathrm{pH} \mathrm{7})$ and mixed for $1 \mathrm{~h}$ at room temperature. The sample was then centrifuged and the metal concentration in the solution was determined. Fraction bound to carbonates (F2) - the residue from the first fraction analysis was treated with $8 \mathrm{ml}$ of $1 \mathrm{~mol} / \mathrm{l}$ sodium acetate acidified with acetic acid to $\mathrm{pH} 5$ and extracted for 8h. Fraction bound to iron and manganese oxides (F3) $-20 \mathrm{ml}$ of $0.04 \mathrm{~mol} / 1 \mathrm{NH}_{2} \mathrm{OH} \times \mathrm{HCl}$ in $25 \%$ acetic acid was added to the residue from the analysis of the second fraction and extracted for $8 \mathrm{~h}$ at a temperature of $96^{\circ} \mathrm{C}$. Fraction bound to organic matter (F4) - the residue from the analysis of the third fraction was mixed with a mixture containing $3 \mathrm{ml}$ of $0.02 \mathrm{~mol} / 1 \mathrm{HNO}_{3}$ and $5 \mathrm{ml}$ of $30 \% \mathrm{H}_{2} \mathrm{O}_{2}$ acidified to $\mathrm{pH} 2$ and heated for $2 \mathrm{~h}$ at $85^{\circ} \mathrm{C}$. Then the solution was cooled and supplied with $3 \mathrm{ml}$ of $30 \% \mathrm{H}_{2} \mathrm{O}_{2}$ acidified to $\mathrm{pH} 2$ and heated at $95^{\circ} \mathrm{C}$ for $3 \mathrm{~h}$. After cooling $5 \mathrm{ml}$ $3.2 \mathrm{~mol} / 1$ of $\mathrm{CH}_{3} \mathrm{COONH}_{4}$ solution in $20 \% \mathrm{HNO}_{3}$ was added and the sample was mixed for $0,5 \mathrm{~h}$. 
Residual fraction (F5) - the sample after the last extraction was mineralized in a mixture of

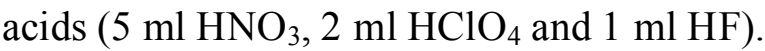

\section{Results and discussion}

The research results showed that the sediments contained heavy load of heavy metals. The average total metal content in sediment samples was equal to $246,6 \mathrm{mgZn} / \mathrm{kg}, 10,1$ $\mathrm{mgCd} / \mathrm{kg}, 148,4 \mathrm{mgPb} / \mathrm{kg}, 132,2 \mathrm{mgCu} / \mathrm{kg}$ dry matter.

Results of single extraction, using three extractants $\left(\mathrm{H}_{2} \mathrm{O}, \mathrm{MgCl}_{2}\right.$ i EDTA) are presented in Figure 1. The water-leaching process showed a considerable degree of their mobility. $4 \% \mathrm{Cu}$, $7 \% \mathrm{Cd}, 10,5 \% \mathrm{~Pb}$ and $20 \% \mathrm{Zn}$ passed into water. Extraction efficiency with $\mathrm{MgCl}_{2}$ solution allows to put metals in the following order: $2,3 \% \mathrm{Cu}, 3 \% \mathrm{Zn}, 13 \% \mathrm{~Pb}$ and $41 \% \mathrm{Cd}$. Metal extraction with $0.05 \mathrm{M}$ EDTA solution removed from sediments on average $11 \% \mathrm{Cd}, 27 \% \mathrm{~Pb}$, $34 \% \mathrm{Zn}$ and $60 \% \mathrm{Cu}$. The most effective extractant for copper and zinc was 0.05M EDTA solution, however, it was not efficient in extraction of lead and cadmium. The most effective solution for releasing $\mathrm{Cd}$ from sediments was magnesium chloride, neutral and of high ionic strength. $\mathrm{Pb}$ was released from the sediments to a similar extent by magnesium chloride and water as extractants. Like $\mathrm{Zn}$ and $\mathrm{Cu}, \mathrm{Pb}$ was extracted most efficiently by the EDT A solution.

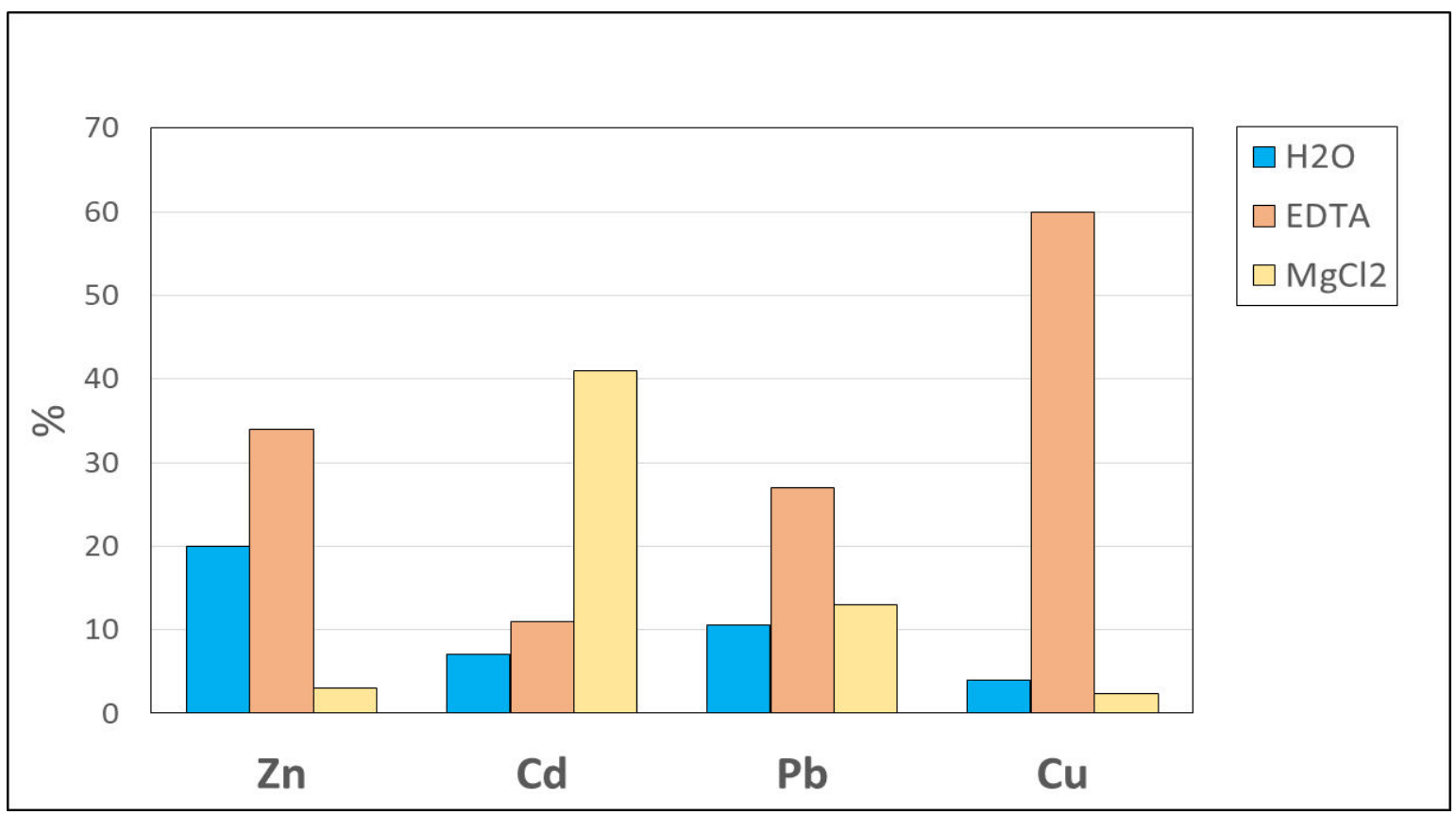

Fig. 1. The percentage of metals extracted from the sediments by water, EDTA and $\mathrm{MgCl}_{2}$.

All bottom sediment samples were subjected to Tessier specimen analysis measuring the $\mathrm{Zn}, \mathrm{Cu}, \mathrm{Pb}$ and $\mathrm{Cd}$ content. Measurable metals bound in 5 fractions (ion exchange, carbonate, adsorption, organic and residual fraction) showed different bioavailability in aqueous environment [12].

Zinc was mostly bound in the hydrated fractions of Fe/Mn oxides $(15,7-49,7 \%)$. The comparable amount of this metal was observed also in the residual fraction (8,3-48,8\%, average$30 \%)$. A significant amount was also in the carbonate fraction $(7,7-46,3 \%)$. This zinc driving separation between sediment fractions may indicate the mobility of contamination containing this metal (fig. 2). Copper was bound strongly in the organic fraction (average 43\%) and the rest fraction (average 42\%) (fig. 2). Similar levels of copper binding in sediments were observed by Akcay et al. [2]. They obtained a high copper content in the residual fraction (F5) in sediment 
samples from Buyak Menderes and Gediz rivers. In the Utrata river sediments, copper showed low content in mobile fractions (exchange, carbonate and adsorption), where the total amount for these three fractions was maximum $23 \%$. Similar results have been obtained for mobile fractions by other researchers: the copper proportions in the first three fractions $(\mathrm{F} 1+\mathrm{F} 2+\mathrm{F} 3)$, with high mobility, did not exceed $15 \%$ of the total content [13].
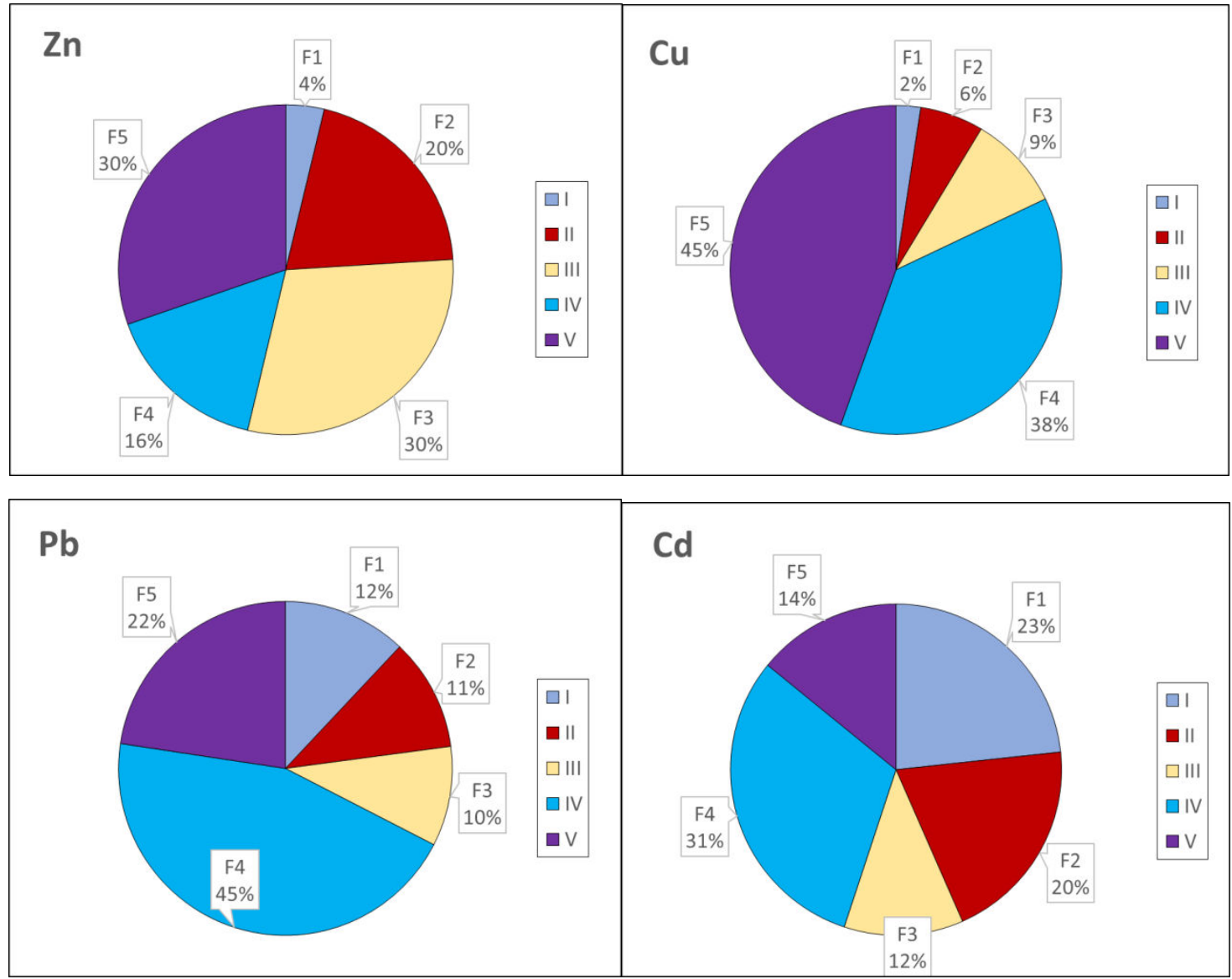

Fig. 2. Percentage of zinc, copper, cadmium, lead forms in the bottom sediments of Utrata river.

The highest amount of cadmium was observed in the organic fraction and in the mobile fractions: exchangeable and carbonate fractions (fig. 2), which proves the strongest bond of cadmium to these fractions. In the other two fractions, the percentage was: in adsorption 3-23\% and in the residual fraction 6- 25\%. The cadmium percentage in mobile fractions (F1, F2, F3) exceeded $50 \%$ and even reached over $60 \%$ of the total content. The high content of reactive cadmium fractions was also obtained by other authors [14]. The lowest involvement in the residual fraction (F5) for Cd was 14\%. Lead, like copper was poorly bound in the exchangeable fraction, stronger in carbonate and adsorption and the strongest bond was observed in organic fraction (fig. 3). In most conducted studies, the results show a high lead affinity for adsorption fraction $[15,16]$. The obtained results for Utrata river bottom sediments indicate a different lead binding ability. Lead present in the sediments remained in high percentages in low reactive fractions. Very low involvement in the residual fraction (fig. 2) was stated for lead (average $23 \%$ ). However, the three bioavailable fractions (F1, F2, F3) periodically contained more than $50 \% \mathrm{~Pb}$.

Heavy metals in sediments are separated between geochemical forms and the bonding degree strongly depends on the sediment composition [18]. Metals from anthropogenic sources are considered to be labile associated with the solid phase surface [19], leading to their mobility 
and bioavailability. Studies have shown a high cadmium content in mobile bottom sediment fractions from Utrata River comparing to other metals. Cadmium, which is strongly bound in these sediment fractions (more than half of the total amount), can be released into water, resulting in an increase of bio- absorbable forms which are toxic to biomass. As a result, the whole environment and the whole food chain is affected. The amount of exchangeable form of $\mathrm{Zn}$ and $\mathrm{Cu}$ in sediments was ineligible. The conducted speciation analysis showed the absolute dominance of the organic fraction in copper and lead binding. Cadmium as well showed strong affinity for this fraction.

The metal binding in individual fractions can be ordered in the following order:

$$
\begin{aligned}
& \text { F1: } \mathrm{Cd}>\mathrm{Pb}>\mathrm{Zn}>\mathrm{Cu} \\
& \text { F2: } \mathrm{Zn}>\mathrm{Cd}>\mathrm{Pb}>\mathrm{Cu} \\
& \text { F3: } \mathrm{Zn}>\mathrm{Cd}>\mathrm{Pb}>\mathrm{Cu} \\
& \text { F4: } \mathrm{Cu}>\mathrm{Pb}>\mathrm{Cd}>\mathrm{Zn} \\
& \text { F5: } \mathrm{Cu}>\mathrm{Pb}>\mathrm{Zn}>\mathrm{Cd}
\end{aligned}
$$

In the Mexican Lerma- Chapala Watershed study, in which only total concentration was analyzed, they found that the sediments transported by the Lerma river to Chapala lake are the final deposition destination of $\mathrm{Cd}, \mathrm{Cr}, \mathrm{Ni}, \mathrm{Cu}, \mathrm{Pb}, \mathrm{Zn}$. A proper risk assessment of the metal migration from contaminated sediments to water in Chapala lake was performed only in the following studies, using a five-step sequence of sequential metal extraction [20].

The metal separation results in Utrata river sediments showed that the exchangeable fraction represented between $11 \%$ and $26 \%$ of the total cadmium content. The second metal with a significant participation in this fraction was lead (6-12\%). For zinc and copper the content in this fraction was much lower, respectively $1,5-5 \%$ and $1,4-3 \%$. Such participation in the F1 fraction indicates that cadmium and lead pose a high risk for flora and fauna located at the bottom part of the river. Percentages of cadmium (13\% -24\%) and lead (4-22\%), similar to those exchangeable fraction, were found also in the carbonate fraction. Zinc also showed a high participation of carbonate binding $(8-46 \%)$. This proved that carbonates fraction had a strong affinity for the testing metals [21]. For copper, the percentage in F2 was very low $(1,9 \%-5,6 \%)$. A high amount of carbonates (average 12\%) was found in contaminated sediments of Utrata river, as well as a significant content (up to $22 \%$ ) of lead in this fraction. Cadmium binding in the reactive carbonate fraction occurred also in the sediments of Volvi and Koronia lakes ([17] and in the river within Iverian Pyrite area on Iberian Peninsula [22]. The carbonate fraction contained a significant amount of total cadmium and lead content in Poraj reservoir sediment [23] and Povang lake [24], lead in Rybnicki reservoir [25] and in reservoir sediments of Kozłowa Góra [26] and cadmium in sediments analyzed by Yang et al. [27]. Our own studies have confirmed the studies of Billon et al. [28], proving that metal ions can be absorbed on the carbonated mineral's surface and then incorporated into crystalline structure, eg $\mathrm{Cd}_{\mathrm{x}} \mathrm{Ca}_{1-\mathrm{x}} \mathrm{CO}_{3}$. The $\mathrm{Cd}$ contribution in the carbonate fraction may be due to the similarity of cadmium and calcium ions. These metals have similar ionic ion radius $\mathrm{Cd}(0,97 \mathrm{~A})$ and $\mathrm{Ca}(0,99 \mathrm{~A})$, so coprecipitatation of cadmium and its incorporation into the crystalline calcite network can occur in the environment [29]. Turka's studies [30] proved that carbonate fraction is dominant for $\mathrm{Pb}$ speciation only when carbonates are a minor part of the sediment composition. Singh et al. [31] observed a similar carbonates role in binding $\mathrm{Pb}$ and $\mathrm{Zn}$ in contaminated sediments of Gomti river, a tributary of the Ganges.

Results, obtained in my own studies, showed the strongest binding of zinc (16-50\%) in the fraction of hydrate oxides of Fe/Mn, which is sensitive to redox potential changes. For the 
residual metals, the average participation in the adsorption fraction was $14 \% \mathrm{Cd}, 8,5 \% \mathrm{~Pb}$ and $7,5 \% \mathrm{Cu}$. Because of large surface, hydrate oxides $\mathrm{Fe} / \mathrm{Mn}$ are one of the most important geochemical phases affecting the mobility and metal behavior in sediments [32]. This was confirmed under the waste water environment conditions of Utrata river, where the precipitation of sparingly soluble iron forms (hydroxides, phosphates) was observed. Zinc sorption may occur on the precipitates [33]. Many studies have confirmed the high adsorption efficiency of hydrated $\mathrm{Fe} / \mathrm{Mn}$ oxides in zinc removal process from water [33, 34].

In studies of bottom sediments from Utrata river, similar to Besser et al. [35] studies, a high content of $\mathrm{Cu}(43 \%), \mathrm{Pb}(43 \%)$ and $\mathrm{Cd}(37 \%)$ in organic and sulfide fractions and low of $\mathrm{Zn}$ (14\%) was confirmed. Wang et al. [34] confirmed the copper presence mainly in organic sulfide fraction. The organic fraction of metals is often assessed as stable, with low hazard. Basing on that, it can be assumed that the concentration of metals in interstitial and benthic water and the concentration of dissolved forms decreases, and thus the toxicity of these metals decreases. Current opinions differ on the metal toxicity bounded by organic substances. Yao et al. [36] studies have shown that metal complexation by organic matter, which serves as nourishment, can increase its toxicity for annelids (oligochaetes). On the other hand, in sediments of shallow Utrata river, where superfluous water layers are well oxygenated and varying hydrological conditions are observed, a high amunt of $\mathrm{Cd}$ in organic and sulphide fraction (F4) may indicate toxicity of $\mathrm{Cd}$ for benthos invertebrates. It is caused by the process where $\mathrm{CdS}$ will be oxidized to the soluble form of $\mathrm{CdSO}_{4}$ in aerobic conditions [34].

The content of the analysed metals in the residual fraction, constituting the insoluble fractions, varied in Utrata river sediments. Metals were associated with this fraction with different strengths for zinc, copper, lead and cadmium, respectively about $26 \%, 42 \%, 37 \%$ i $13 \%$ of total content. This part of metal is theoretically inaccessible to microorganisms and should not be activated in predictable time. In sediment studies from Poraj reservoir, which is tributary with Warta river waters [23], Kozłowa Góra reservoir sediments [26], sediments from Dongting lake [36] or Taihu lake [37] have shown a significant role of residual fraction in binding zinc process. Fityanos et al. [17] used a five- step metal extraction procedure to evaluate the assessment of sediment contamination by six metals $(\mathrm{Cd}, \mathrm{Cr}, \mathrm{Pb}, \mathrm{Mn}, \mathrm{Zn}, \mathrm{Cu}$ ) in two lakes (Volvi and Koronia), in northern Greece. Their results showed that $\mathrm{Cd}, \mathrm{Cr}, \mathrm{Cu}$ and $\mathrm{Pb}$ were mainly associated with the residual fraction and, to a lower extent, with carbonate fraction, posing a low risk of secondary lakes contamination.

A single extraction was performed to confirm the results of sequential extraction of the labile metal binding in sediments. The degree of water-leaching of lead and zinc was more than 10 percent, while cadmium and copper up to 10 percent. This has confirmed the labile nature of the metal binding in sediments and high probability of passing them to the dissolved phase. Using a $\mathrm{MgCl}_{2}$ solution with stable $\mathrm{pH}$ and high ionic strength for extraction, a higher degree of elution with respect to cadmium $(>40 \%)$ and lead $(>10 \%)$ was obtained for the extraction and low for copper and zinc $(<5 \%)$. Extraction with $\mathrm{MgCl}_{2}$ showed higher results than extraction with water, which was due to the character of magnesium chloride and the competitiveness of heavy metal cations with respect to the large $\mathrm{Mg}^{2+}$ ion. High concentrations of metals were obtained in EDTA extracts. The affinity for the chelating solution was predominantly copper, passing to the solution in about $60 \%$. Lower extraction efficiency was found for zinc and lead, the lowest for cadmium.

Significant metal leaching ability with water and used solutions, indicates the presence of metals in mobile forms, which is typical for short time deposited sediments. Mobility of the 
metals bound in sediments depends on their individual properties and the composition of the over sedimentary water and the variable character of sediments. Under the conditions simulating minor environmental changes (magnesium chloride effluent), more toxic metals $(\mathrm{Cd}$ and $\mathrm{Pb})$ were released, indicating a high bioavailability of their forms. Similar metal behaviour was observed in studies and research conducted in the Amur, Rhine and Dommel river valleys [38, 39,40 ] and in the middle part of Vistula valley [41]. Metals reaching the aquatic environment are deposited in bottom sediments and temporarily immobilized, but may pose a threat to aquatic life. Under favourable conditions, metals may be released back into the water and then incorporated into the trophic chain and participate in further biological cycle stages. Changing environmental conditions can transform metal forms into sediments and change their bioavailability. Therefore, knowledge of the metal form contribution in sediments is necessary to describe their mobility and bioavailability in the aquatic environment as well as, in risk assessment. The metal tendencies for migration depend on their sediment forms, which are indicators of long term changes of water pollution and biological and chemical changes in the aquatic environment.

\section{Conclusions}

Heavy metals accumulation in the surface sediment layer is an ecological reflection of the rivers conditions and as well as the intensified anthropopression associated with the progressive urbanization of the catchment area. Metal fractionation showed different strength in metal binding processes in five bottom sediment fractions. Significant amounts of metals were bound in mobile fractions, indicating their high bioavailability. Possibility of heavy metal remobilisation from the bottom sediments to deep water, indicates a postponed environmental hazard. An important element of the bottom sediment research testing tool is use of more than one analytical method (simple and sequential extraction). Conducted research proved that sequential analysis of metal specimens should be co-used with single extraction to evaluate the metals transformation in biogeochemical cycles in aqueous environmental, which significantly reduced ambiguous results and misinterpreted them. The results of single and sequential extraction in conducted research, proved correct, indicating the potential possibility of metal migration in water-sediment system as a result of water quality parameters, indicating their mobility and bioavailability.

\section{References}

[1] A.S. Jumbe, N. Nandini, "Heavy metals analysis and sediment quality values in urban lakes", American Journal of Environmental Sciences, volume 5, issue 6, pp. 678-687, 2009.

[2] H. Akcay, A. Oguz, C. Karapire, "Study of heavy metal pollution and speciation in Buyak Menderes and Gediz river sediments", Water Research, vol 37, pp. 813-822, 2003.

[3] J. E. Fergusson, The heavy elements: chemistry, environmental impact, and health effects, New Zealand, Pergamon Press, 1991.

[4] A. Karczewska, "Evaluation of the importance of iron and manganese oxides in the sorption of heavy metals in polluted soils, in light of sequential extraction", Annals PZH, vol. 55, pp. 119-127, 2004

[5] M. Wojtkowska, "Migration and Forms of Metal in Bottom Sediments of Czerniakowskie Lake", The Bul of Environ Contam and Tox, vol. 90, no. 2, pp. 165-169, 2013. 
[6] C. Sudesh, B. K. Deepak, K. Naresh, Y. Sudesh, "Assessment of bioavailable metals in the sediments of Yamuna flood plain using two different single extraction procedures", Sust Environ Res, vol. 26, no. 1, pp. 28-32, 2016.

[7] A. Ibragimow, G. Głosińska, M. Siepak, B. Walna, "Initial investigations of heavy metal pollution of sediments in flood plains", Wor and Geogl Stud, vol. 44, pp. 233-247, 2010.

[8] N. Finzgar, D. Lestan, "Multi-step leaching of $\mathrm{Pb}$ and $\mathrm{Zn}$ contaminated soils with EDTA", Chemosphere, vol. 660, pp. 824-832, 2007.

[9] A.M. Ure, P. Quevauviller, H. Mantau, B.Griepink, "Speciation of heavy metals in soils and sediments. An account of the improvement and harmonization of extraction techniques undertaken under the auspices of the BRC of the Commission of the 63 European Communities", Int. J of Environ Anal Chem, vol. 51, pp. 135-151, 1993.

[10] A.Tessier, P.G.C.Campbell, M. Bisson, "Sequential extraction procedure for the speciation of particulate trace metals", Anall Chem, vol. 51, no.7, pp.44-351, 1979.

[11] M.Wojtkowska, "Content of selected heavy metals in water and riverbed sediments of the Utrata river", Environ Prot Eng, vol.3, no. 37, pp. 55-62, 2011.

[12] M. Wojtkowska, J. Bogacki, A. Witeska, "Assessment of the hazard posed by metal forms in water and sediments", Sci of the Total Environt, vol. 551-552, pp. 387-392, 2016.

[13] D.M. Dong, H.L. Li, Y. Li, C.S. Fang, X.H. Li, C.Y. Xu, "Distribution of heavy metals in the sediments from the Yitong River: Changchun Section", Res of Soil and Water Cons, vol. 11, no.1 $13695-96,2004$.

[14] K. Fytianos and A. Lourantou, "Speciation of elements in sediment samples collected at lakes Volvi and Koronia, N. Greece", Environment International, vol. 30, no. 1, pp. 11-17, 2004. Available: 10.1016/s0160-4120(03)00143-0 [Accessed 5 June 2019].0

[15] D. RELIC, D. DORDEVIC, A. POPOVIC and T. BLAGOJEVIC, "Speciations of trace metals in the Danube alluvial sediments within an oil refinery", Environment International, vol. 31, no. 5, pp. 661-669, 2005. Available: 10.1016/j.envint.2004.11.003..

[16] S.P. Feng, L.Liang, Y. Zhu, X.D. Zou, X.D. Zhang, "Speciation analysis of the river sediment (II)-Tessier sequential chemical extraction procedures", J Shand Univ, vol. 39, no. 6, no. 107, pp. 101-104, 2004.

[17] K. Fytianos and A. Lourantou, "Speciation of elements in sediment samples collected at lakes Volvi and Koronia, N. Greece", Environment International, vol. 30, no. 1, pp. 11-17, 2004. Available: 10.1016/s0160-4120(03)00143-0..

[18] J.M. Alvarez, L.M. Lopez-Valdivia, J.Novillo, A. Obrador, M.I. Rico, "Comparison of EDTA and sequential extraction tests for phytoavailability prediction of manganese and zinc in agricultural alkaline soils", Geoderma, vol. 132, pp. 450-463, 2006.

[19] L. Samsoe-Petersen, E.H.Larsen, P.B. Larsen, P. Brun, "Uptake of trace elements and PAHS by fruit and vegetable from contaminated soils", Environ Scie \& Techn, vol. 36, pp. 3057-3063, 2002.

[20] J.L. Trujillo-Cárdenas, N.P. Saucedo-Torres, P.F. Zárate del Valle, N.R. Donato, E. Mendizábal, S. Gómez-Salazarb, "Speciation and Sources of Toxic Metals in Sediments of Lake Chapala", J. Mexico Chem Soci, vol.54, no. 2, pp.79-87, 2010.

[21] J. Lu, Z. Huang and X. Han, "Water and heat transport in hilly red soil of southern China: I. Experiment and analysis", Journal of Zhejiang University SCIENCE, vol. 6, no. 5, pp. 331-337, 2005. Available: 10.1631/jzus.2005.b0331 [Accessed 5 June 2019]..

[22] A. Romero, I. Gonzalez and E. Galan, "THE ROLE OF EFFLORESCENT SULFATES IN THE STORAGE OF TRACE ELEMENTS IN STREAM WATERS POLLUTED BY 
ACID MINE-DRAINAGE: THE CASE OF PENA DEL HIERRO, SOUTHWESTERN SPAIN", The Canadian Mineralogist, vol. 44, no. 6, pp. 1431-1446, 2006. Available: 10.2113/gscanmin.44.6.1431.

[23] A. Rosińska, L. Dąbrowska, "PCBs and heavy metals in bottom sediments of the dam reservoir in Poraj.", Ing. and Och. Env., vol.4, no.11, pp. 455-469, 2008.

[24] M. Luo, J. Li, W. Cao, M. Wang, "Study of heavy metal speciation in branch sediments of Poyang Lake", J. of Env Scie, vol. 20, pp. 161-166, 2008.

[25] K. Loska, D. Wiechuła, G.Pęciak, "The use of speciation analysis in the study of metal bioavailability in the bottom sediment of Rybnik Reservoir", Ecol Problems, vol. 2, no. 7, pp. 69-74, 2003.

[26] L. Dąbrowska, "Specialization of heavy metals in bottom sediments of the Kozłowa Góra reservoir", Environ Prot and Nat Res, vol. 49, pp. 354 - 364, 2011.

[27] S. Yang, J. Zhang and X. Xu, "Influence of the Three Gorges Dam on downstream delivery of sediment and its environmental implications, Yangtze River", Geophysical Research Letters, vol. 34, no. 10, 2007. Available: 10.1029/2007gl029472 [Accessed 5 June 2019]..

[28] G. Billon, B. Ouddane, P. Recourt and A. Boughriet, "Depth Variability and some Geochemical Characteristics of Fe, Mn, Ca, Mg, Sr, S, P, Cd and Zn in Anoxic Sediments from Authie Bay (Northern France)", Estuarine, Coastal and Shelf Science, vol. 55, no. 2, pp. 167-181, 2002. Available: 10.1006/ecss.2001.0894 [Accessed 5 June 2019]..

[29] C. Ianni, E. Magi, P. Rivaro and N. Ruggieri, "Trace metals in Adriatic coastal sediments: Distribution and speciation pattern", Toxicological \& Environmental Chemistry, vol. 78, no. 1-2, pp. 73-92, 2000. Available: 10.1080/02772240009358961 [Accessed 5 June 2019].

[30] A. Turki, "Metal Speciation ( $\mathrm{Cd}, \mathrm{Cu}, \mathrm{Pb}$ and $\mathrm{Zn}$ ) in Sediments from Al Shabab Lagoon, Jeddah, Saudi Arabia", Journal of King Abdulaziz University-Marine Sciences, vol. 18, no. 1, pp. 191-210, 2007. Available: 10.4197/mar.18-1.11.

[31] K.P. Singh, D.Mohan, V.K. Singh, A. Malik, "Studies on Distribution and Fractionation of Heavy Metals in Gomi River Sediments-A Tributary of Ganges”, Ind. J. Hyd., vol. 312, pp. 14-27, 2005.

[32] A. Turner, S.M. Le Roux, G.E. Millward, "Adsorption of cadmium to iron and manganese oxides during estuarine mixing”, Mar. Chem., vol. 108, pp. 77-84, 2008.

[33] R.A. Root, S. Dixit, K.M. Campbell, A.D. Jew, J.G.Hering, P.A. O’Day, “Arsenic sequestration by sorption processes in high-iron sediments", Geochem. et Cosm. Act., vol. 71, pp. 5782-5803, 2007.

[34] S. Wang, Y. Jia, S. Wang, X. Wang, H. Wang, Z. Zhao, B. Liu, "Fractionation of heavy metals in shallow marine sediments from Jinzhou Bay", China, J. Env. Sci., vol. 22, no. 1, pp. 23-31, 2010.

[35] J.M. Besser, W.G. Brumbaugh, T.W. May, C.G. ngersoll, (2003) Effects of organic amendments on the toxicity and bioavailability of cadmium and copper in spiked formulated sediments, Environ Tox and Chem. 22 805-815.

[36] Z. Yao, P. Gao., "Heavy metal research in lacustrine sediment: a review". Chin J. of Ocean and Limn, vol. 25, no. 3, pp. 444-454, 2007.

[37] Z. Yao, "Comparison between BCR sequential extraction and geo-accumulation method to evaluate metal mobility in sediments of Dongting Lake, Central China", Chinese Journal 
of Oceanology and Limnology, vol. 26, no. 1, pp. 14-22, 2008. Available: 10.1007/s00343008-0014-7 [Accessed 5 June 2019].

[38] E. Bleeker and C. van Gestel, "Effects of spatial and temporal variation in metal availability on earthworms in floodplain soils of the river Dommel, The Netherlands", Environmental Pollution, vol. 148, no. 3, pp. 824-832, 2007. Available: 10.1016/j.envpol.2007.01.034 [Accessed 5 June 2019].

[39] A.M. Schipper, S.Wijnhoven, R.S.E.W. Leuven, A.M.J. Ragas, A.J. Hendriks, "Spetial distribution and internal metal contrations of terrestrial arthropods in a moderately contaminated lowland floodplain along the Rhine River", Env. Pol., vol. 151, pp. 17-26, 2008.

[40] C.A.M., Van Gestel "Physico-chemical and biological parameters determine metal bioavaiability in soils.", Sci. Tot. Env., vol. 406, pp. 385-395, 2008.

[41] J.Gąsior, J.Paśko, "Effect of flood on the content of soluble forms of elements on the background of soil diversity”, Probl J of Agric Prog, vol. 520, pp. 39-46, 2007. 